\title{
Molecular characterization of multidrug-resistant extended-spectrum $\beta$-lactamase-producing Enterobacteriaceae isolated in Antananarivo, Madagascar
}

\author{
Hanitra C Rakotonirina ${ }^{1,4^{*}}$, Benoît Garin ${ }^{1}$, Frédérique Randrianirina ${ }^{1}$, Vincent Richard ${ }^{1,2}$, Antoine Talarmin ${ }^{1,3}$
} and Guillaume Arlet ${ }^{4,5}$

\begin{abstract}
Background: We investigated the molecular characteristics of multidrug-resistant, extended-spectrum $\beta$-lactamase (ESBL)-producing Enterobacteriaceae isolated in community settings and in hospitals in Antananarivo, Madagascar.

Results: Forty-nine E. coli, K. pneumoniae, K. oxytoca and E. cloacae ESBL-producing isolates were studied. In antimicrobial susceptibility analyses, many of the isolates exhibited resistance to aminoglycosides, fluoroquinolones and trimethoprim-sulfamethoxazole. Gene amplification analysis and sequencing revealed that $75.5 \%(n=37)$ of the isolates harbored bla $a_{\mathrm{CTX}-\mathrm{M}-15}$ and $38.7 \%(\mathrm{n}=19)$ harbored b/a $a_{\mathrm{SHV}-12}$. The non-ESBLs resistance genes detected were bla TEM-1, bla OXA-1, aac $\left(6^{\prime}\right)-1 b$, aac $\left(6^{\prime}\right)-1 b-c r$, tetA, sul-1, sul-2, anrA, anrB and catB-3. We found dfrA and aadA gene cassettes in the class 1 integron variable regions of the isolates, and the combination of dfrA17-aadA5 to be the most prevalent. All bla $a_{\mathrm{CTX}-\mathrm{M}-15}$ positive isolates also contained the ISECP1 insertion element. Conjugation and transformation experiments indicated that $70.3 \%$ of the antibiotic resistance genes resided on plasmids. Through a PCR based replicon typing method, plasmids carrying the bla $a_{\mathrm{SHV}-12}$ or bla $a_{\mathrm{CTX}-\mathrm{M}-15}$ genes were assigned to either the IncFII replicon type or, rarely, to the HI2 replicon type. All isolates were subtyped by the rep-PCR and ERIC-PCR methods. Phylogenetic grouping and virulence genotyping of the $E$. coli isolates revealed that most of them belonged to group A1. One isolate assigned to group B2 harbored bla $a_{C T X-M-15}$ and five virulence genes (traT, fyuA, iutA, iha and sfa) and was related to the O25b-ST131 clone.
\end{abstract}

Conclusions: Our results highlight the dissemination of multidrug resistant Enterobacteriaceae isolates in Antananarivo. These findings underline the need for a rational use of antibiotic and for appropriate methods of screening ESBL in routine laboratories in Antananarivo.

\section{Background}

Extended-spectrum $\beta$-lactamase (ESBL)-producing bacteria represent a major worldwide threat among drug-resistant bacteria in both hospital and community settings [1]. ESBLs are among the Ambler classes A, confer resistance to $\beta$-lactam antibiotics except cephamycins and carbapenems, and are inhibited by clavulanic acid [1]. ESBLs are often located on large plasmids that also harbor resistant

\footnotetext{
* Correspondence: clara@pasteur.mg

${ }^{1}$ Institut Pasteur de Madagascar, Antananarivo 101, BP 1274, Madagascar

${ }^{4}$ Faculté de Médecine, Laboratoire de Bactériologie, Université Pierre et Marie Curie, Paris 6, 27 rue Chaligny, Paris 75012, France

Full list of author information is available at the end of the article
}

genes to other antimicrobial classes with resulting multidrug-resistant isolates [2].

The first ESBLs have evolved by genetic mutation from native $\beta$-lactamases TEM and SHV [3] [4]. Recently, a novel type of ESBLs, the CTX-M enzymes, emerged worldwide, mostly from Enterobacteriaceae [5,6]. CTX-M $\beta$-lactamases are not closely related to TEM or SHV ESBLs but share high amino-acid identity with chromosomal $\beta$-lactamases from Kluyvera spp. [7]. Now, bla $a_{C T X-\mathrm{M}-15}$ is recognized as the most widely distributed CTX-M enzyme [8]. It is derived from CTX-M-3 by a substitution of Asp-240-Gly which increases its catalytic efficiency against ceftazidime [9]. $b l a_{\mathrm{CTX}-\mathrm{M}-15}$ are encoded

\section{() BioMed Central}

(c) 2013 Rakotonirina et al.; licensee BioMed Central Ltd. This is an Open Access article distributed under the terms of the Creative Commons Attribution License (http://creativecommons.org/licenses/by/2.0), which permits unrestricted use, distribution, and reproduction in any medium, provided the original work is properly cited. 
on plasmids belonging to the incompatibility group IncF [10]. In the upstream region of CTX-M genes an insertion sequence element, ISEcp 1, is commonly present and is likely responsible for the transposition process of the genes [11].

E. coli is among the most prevalent causes of hospitalacquired and community-acquired bacterial infections and their resistances to antimicrobial agents have become a serious concern for healthcare providers [5]. Phylogenetic analyses have classified $E$. coli into four main phylogenetic groups (A, B1, B2, and D). Commensal isolates belong mainly to $\mathrm{A}$ and $\mathrm{B} 1$ groups whereas virulent extraintestinal pathogenic E. coli (ExPEC) are essentially from the B2 and D groups [12,13]. ExPEC harbor numerous virulence factors including $\alpha$-hemolysin, cytotoxic necrotizing factor, adhesins and iron acquisition systems [12]. The spread of $b l a_{\mathrm{CTX}-\mathrm{M}-15}$ has been mainly associated with the dissemination of a particular clone of E. coli ST131 belonging to phylogenetic group B2 [14,15]. Recently, an E. coli clone O25 ST131, producing CTX-M -15 , with high virulence potential and belonging to the B2 group, has been reported and represent a major public health problem $[14,15]$.

Many reports have documented the emergence of ESBLproducing Enterobacteriaceae [16-18]. In Antananarivo, ESBLs were first detected in 2005 from UTI in 9.7\% of isolated Enterobacteriaceae [19]. In 2006, outbreaks of CTX-M-15 and SHV-2-producing K. pneumoniae isolates have been described in two pediatric units [20]. More recently, $21.3 \%$ of clinical isolates from patients in surgery and intensive care units [21] and $21.2 \%$ of intestinal carriage isolates from children hospitalized in a pediatric department of a large teaching hospital [22] were ESBLproducers.

For 49 multidrug-resistant Enterobacteriaceae isolates from Antananarivo, we characterized: i) the genes encoding the ESBLs; ii) the drug resistance genes associated with the ESBL genes; iii) gene cassettes present in the isolates; and iv) the plasmid incompatibility groups of the isolates. We also determined the phylogenetic groups and virulence factors of the $E$. coli isolates.

\section{Methods}

\section{Ethical clearance}

The study protocols were approved by the National Ethics Committee of Madagascar. Written informed consents were obtained from all patients and at least one parent of each child before enrollment.

\section{Patients}

Between September 2006 and December 2007, a total of 909 non-duplicate bacterial isolates were obtained from 909 patients. 830 patients were recruited from several wards in four hospitals in Antananarivo, Madagascar (two national university teaching hospitals: Joseph Ravoahangy Andrianavalona Hospital and Befelatanana Hospital; a military hospital: Soavinandriana Hospital; and a pediatric hospital: Tsaralalana Hospital) and 79 patients referred to the Pasteur Institute Medical Laboratory in Antananarivo.

\section{Laboratory methods}

Various clinical specimens (including blood-culture, urine, pus, sputum and CSF) were collected and submitted for bacterial analysis at the Pasteur Institute Medical Laboratory in Antananarivo. Presumptive Enterobacteria isolates were identified using standard microbiological methods and the API 20E system (Bio-Mérieux SA, Marcy l'Etoile, France).

\section{Antimicrobial susceptibility testing and ESBL detection}

Antimicrobial susceptibilities were determined by the disk diffusion method on Mueller-Hinton agar (Bio-Rad, Marne la Coquette, France) according to the guidelines of the Comité de l'antibiogramme de la Société Française de Microbiologie. The following antibiotics were tested: amoxicillin, amoxicillin-clavulanate, ticarcillin, cephalotin, cefamandole, cefoxitin, cefotaxime, ceftazidime, imipenem, gentamicin, tobramycin, netilmicin, amikacin, nalidixic acid, pefloxacin, ciprofloxacin and trimethoprim-sulfamethoxazole.

Suspected ESBLs were confirmed by the double-disk synergy test. E. coli ATCC 25922 and K. pneumoniae ATCC 700603 were used as quality control strains.

\section{Fingerprinting analysis}

After DNA extraction by using the Qiagen Mini kit (Qiagen, Courtaboeuf, France), repetitive extragenic palindromic (Rep-PCR) and Enterobacterial repetitive intergenic consensus sequence PCR (ERIC-PCR) were performed with the rep-1R, rep-2 T and ERIC-2 primers, respectively, as previously described [18]. Pattern profiles were considered different when at least one band differed.

\section{Molecular characterization of resistance genes}

DNA was extracted by the boiling method. ESBL-encoding genes were identified using specific primers for the $b l a_{\mathrm{TEM}}$, $b l a_{\mathrm{SHV}}, b l a_{\mathrm{CTX}-\mathrm{M}}$ and $b l a_{\mathrm{OXA}}$ genes, previously described [23], and followed by DNA sequencing. Other bla $a_{\mathrm{CTX}-\mathrm{M}-15^{-}}$ associated antibiotic resistance genes (i.e., $a a c\left(6^{\prime}\right)-I b, q n r A$, $q n r B, q n r S$, tetA, sul1 and sul2) were screened by PCR $[24,25]$. All positive isolates for the $a a c\left(6^{\prime}\right)-I b$ gene were further analyzed by digesting the purified PCR products with BtsCI (New England Biolabs, Beverly, MA) to identify $a a c\left(6^{\prime}\right)-I b-c r$, which lacks the BtsCI restriction site present in the wild-type gene [26]. The upstream sequence of the bla sequenced to detect ISEcp1. The integrase gene (int 1 ) 
was detected by PCR using specific primers [27]. The variable region of each class 1 integron was amplified using specific primers for the $5^{\prime}$ conserved segment $\left(5^{\prime} \mathrm{CS}\right)$ and $3^{\prime}$ conserved segment $\left(3^{\prime} \mathrm{CS}\right)$ [27], and gene cassettes were sequenced. BlastN was used to compare the sequences obtained to those present in the GenBank database (http://blast.ncbi.nlm.nih.gov).

\section{Resistance transfer assays}

Conjugations were carried out in trypticase soy broth (Bio-Rad), with E. coli J53-2 (pro, met, Rif') as the recipient. Mating broths were incubated at $37^{\circ} \mathrm{C}$ for $18 \mathrm{hr}$. Transconjugants were selected on Drigalski agar plates (Bio-Rad) containing rifampicin $(250 \mu \mathrm{g} / \mathrm{ml})$ and cefotaxime $(2.5 \mu \mathrm{g} / \mathrm{ml})$.

Transfer experiments using electroporation were performed for non-conjugative plasmids. Plasmid DNA from donors was extracted with a QIAGEN plasmid midi kit (QIAGEN, Courtaboeuf, France). Purified plasmids were used to transform E. coli DH10B (Invitrogen SARL, Cergy-Pontoise, France) by electroporation following the manufacturer's instructions (Bio-Rad). Transformants were incubated at $37^{\circ} \mathrm{C}$ for $1.5 \mathrm{hr}$ and then selected on Drigalski agar (Bio-Rad) supplemented with $2.5 \mu \mathrm{g} / \mathrm{ml}$ cefotaxime.

Transconjugants and transformants were tested for ESBL production followed by PCR amplification of the ESBL genes and plasmid replicon typing.

\section{Plasmid replicon type determination}

Plasmid replicons from transconjugants and transformants were determined using the PCR-based replicon typing method described previously by Carattoli et al. Eighteen pairs of primers targeting the FIA, FIB, FIC, HI1, HI2, I1, L/M, N, P, W, T, A/C, K, B/O, X, Y, F and FII replicons were used in single or multiplex PCR [28].

\section{Phylogenetic group and virulence genotyping of $E$. coli}

The phylogenetic groups of the $E$. coli isolates were determined by PCR, [13], using a combination of three DNA gene markers (chuA, yjaA and TSPE4-C2). All isolates belonging to group B2 were analyzed by duplex PCR targeting the $p a b B$ and trpA genes to determine whether the isolate was a member of the O25b-ST131 clonal group or not [29].

The presence of 15 virulence factors found in ExPEC was investigated by PCR with primers reported previously [16]. These factors included fimH (type 1 fimbriae), sfa/foc (S and F1C fimbriae), pap $G$ alleles ( $\mathrm{G}$ adhesin classes of $\mathrm{P}$ fimbriae), afa (fimbrial adhesin), hlyA (alpha-haemolysin A), $\operatorname{cnf}$ (cytotoxic necrotizating factor 1), fyuA (genes of yersiniabactin), iutA (aerobactin receptor), kpsMII (group 2 capsules), $\operatorname{traT}$ (genes related to complement resistance), sat (secreted autotransporter toxin), IroN (iron related genes) and Iha (IrgA homologue adhesin).

\section{Results}

\section{Description of the bacterial isolates}

During the study period, we collected 909 isolates, of which 830 from hospitalized patients and 79 from patients attending the Pasteur Institute medical laboratory. Among these, 262 were identified as E. coli $(\mathrm{n}=75), K$. pneumoniae $(\mathrm{n}=95), K$. oxytoca $(\mathrm{n}=12)$ or E. cloacae $(\mathrm{n}=80)$ and 239 were ESBL-producers of which 49 were selected for in-depth analysis. Inclusion criteria were: i) one isolate per patient; ii) only the referent isolate, in cases of a hospital outbreak; and iii) at least one isolate from every ward participating in the study.

Among the 49 ESBL-producing isolates, 13 were isolated from patients referred to the Pasteur Institute Medical Laboratory and 36 were from hospitalized patients. Distribution of isolates by hospital, ward and specimen is shown in Table 1.

Antimicrobial susceptibility analyses showed that all isolates were resistant to all the $\beta$-lactams used but were susceptible to cefoxitin and imipenem. Resistance to cefoxitin in all E. cloacae isolates was due to the inducible production of $A m p C \beta$-lactamase from a chromosomal gene. All ESBL-producing isolates were also multidrug-resistant and most of them were resistant to: aminoglycosides $(87.7 \%$ to gentamicin, $93.8 \%$ to tobramycin), trimethoprim-sulfamethoxazole (100\%) and quinolones (75.5\% to nalidixic acid, $69.3 \%$ to ciprofloxacin).

\section{Molecular epidemiology}

ERIC-PCR and rep-PCR analyses revealed different restriction patterns for each isolate and showed that they were not clonally related (data not shown).

\section{Molecular analysis}

Nucleotide sequence analysis of the $b l a_{\mathrm{CTX}-\mathrm{M}}$ and $b l a_{\mathrm{SHV}}$ genes showed that only the CTX-M-15 and SHV-12 genes were present in these isolates. Only TEM-1 and OXA-1 were identified in the TEM- and OXA-producing isolates.

The CTX-M-15 gene was detected in 37 isolates (75.5\%) and the SHV-12 gene in 19 (38\%). The ISEcp1 insertion sequence was identified in all $37 b^{b} a_{\mathrm{CTX}-\mathrm{M}^{-}}$-carrying isolates. Of the 37 isolates positive for CTX-M-15, ten (27\%) also carried only TEM-1, nine (24.3\%) also carried only OXA-1, and 16 (43.2\%) carried TEM-1 and OXA-1 genes (Table 1). Of the 19 SHV-12-positive isolates, six (31.6\%) also carried only TEM-1, four (20.1\%) also carried only OXA-1 and six (31.6\%) carried TEM-1 and OXA-1 genes (Table 1). Eight isolates (16.3\%) (two E. coli, five $K$. pneumoniae and one E. cloacae) carried both bla ${ }_{\mathrm{CTXM}-15}$ and $b l a_{\mathrm{SHV}-12}$ and six of these were additionally TEM-1and OXA-1-positive.

The resistance genes most frequently present were aac (6')-Ib ( $\mathrm{n}=35,71.4 \%)$ (33 were aac $\left.\left(6^{\prime}\right)-I b-c r, 67.3 \%\right)$, sul1 and sul $2(\mathrm{n}=25,51 \%)$, tet $A(\mathrm{n}=24,48.9 \%)$, qnrB $(\mathrm{n}=12$, 
Table 1 Distribution of isolates among patient category, ward and specimen types

\begin{tabular}{|c|c|c|c|c|c|c|c|c|c|c|c|c|c|c|c|c|c|}
\hline \multirow[b]{2}{*}{ Species } & \multirow[b]{2}{*}{ No } & \multirow[b]{2}{*}{ Hospital } & \multirow[b]{2}{*}{ IPM } & \multicolumn{4}{|c|}{ Hospital } & \multicolumn{6}{|c|}{ Ward } & \multicolumn{4}{|c|}{ Specimen } \\
\hline & & & & HJRA & HOMI & Befelatanana & Tsaralalana & Surgery & Trauma & Intensive care & Pediatrics & Urology & Dermato & Pus & Blood & Urine & Other* \\
\hline E. cloacae & 14 & 12 & 2 & 8 & 2 & 1 & 1 & 2 & 5 & 1 & 3 & 1 & 0 & 9 & 4 & 1 & 0 \\
\hline E. coli & 18 & 14 & 4 & 12 & 2 & 0 & 0 & 3 & 6 & 3 & 0 & 1 & 1 & 12 & 0 & 4 & 2 \\
\hline K. pneumoniae & 14 & 7 & 7 & 4 & 3 & 0 & 0 & 1 & 3 & 3 & 0 & 0 & 0 & 6 & 3 & 5 & 0 \\
\hline K. oxytoca & 3 & 3 & 0 & 0 & 1 & 1 & 1 & 0 & 0 & 1 & 2 & 0 & 0 & 0 & 3 & 0 & 0 \\
\hline No (\%) & $\begin{array}{l}49 \\
(\%)\end{array}$ & $\begin{array}{c}36 \\
(73.5)\end{array}$ & $\begin{array}{c}13 \\
(26.5)\end{array}$ & $\begin{array}{c}24 \\
(49)\end{array}$ & $\begin{array}{c}\mathbf{8} \\
(16.3)\end{array}$ & $\begin{array}{c}\mathbf{2} \\
(4.1)\end{array}$ & $\begin{array}{c}\mathbf{2} \\
(4.1)\end{array}$ & $\begin{array}{c}\mathbf{6} \\
(12.2)\end{array}$ & $\begin{array}{c}14 \\
(28.6)\end{array}$ & $\begin{array}{c}\mathbf{8} \\
(16.3)\end{array}$ & $\begin{array}{c}\mathbf{5} \\
(10.2)\end{array}$ & $\begin{array}{c}\mathbf{2} \\
(4.1)\end{array}$ & $\begin{array}{c}\mathbf{1} \\
(2)\end{array}$ & $\begin{array}{c}\mathbf{2 7} \\
(55.1)\end{array}$ & $\begin{array}{c}10 \\
(20.4)\end{array}$ & $\begin{array}{c}10 \\
(20.4)\end{array}$ & $\begin{array}{c}\mathbf{2} \\
(4.1)\end{array}$ \\
\hline
\end{tabular}

*Other: CSF, sputum.

IPM: Pasteur Institute Medical Laboratory.

HJRA: Joseph Ravoahangy Andrianavalona Hospital.

HOMI: Military Hospital. 
$24.5 \%)$ and $q n r A(\mathrm{n}=1,2 \%)$. Among the six isolates carrying $b l a_{\mathrm{CTXM-15}}, b l a_{\mathrm{SHV}-12}, b l a_{\mathrm{TEM}-1}$ and $b l a_{\mathrm{OXA}-1}$, all of these also carried $a a c\left(6^{\prime}\right)-I b$ (5 were $\left.a a c\left(6^{\prime}\right)-I b-c r\right)$, sul1-sul2, and five harbored tetA.

Overall $\beta$-lactam resistant isolates harbored $\beta$-lactamases genes (CTX-M-15, SHV-12, TEM-1 and/or OXA-1) as well as trimethoprim-sulfamethoxazole resistant isolates sulfamide genes (sul1 and/or sul2). Ten (27.8\%) of ciprofloxacin resistant isolates and 3 (25\%) of ciprofloxacin susceptible isolates were $q n r$ positive. Twenty five (69.2\%) of ciprofloxacin resistant isolates and 8 (61.5\%) of ciprofloxacin susceptible isolates were $a a c\left(6^{\prime}\right)-I b-c r$ positive And, 27 (71\%) of amikacin susceptible isolates and $8(72.7 \%)$ of amikacin resistant isolates were aac (6')- $I b$ positive.

Forty-eight isolates were positive for the class-1 integron gene and it was absent in only one $K$. oxytoca isolate. We amplified the class 1 integrons in twenty-five (52\%) of these 48 isolates using $5^{\prime} \mathrm{CS}$ and $3^{\prime} \mathrm{CS}$ primers. The sizes of the class 1 integron amplicons, which correspond to the approximate sizes of the cassette regions, were between $0.7 \mathrm{~kb}$ and $2 \mathrm{~kb}$. Seven different cassettes were identified, including the $d f r$ gene that encodes resistance to trimethoprim and the aad $A$ gene that encodes resistance to streptomycin. The two genes most frequently associated with each other were $d$ fr $A 17$ and aadA5 (11/25, 22.4\%) (Table 2).

\section{Resistance transfer}

Transfer of ESBL by conjugation to E. coli J53-2 was successful for 29 (59.2\%) of the $49 \mathrm{ESBL}$ isolates, which consisted of eight $E$. coli, eight E. cloacae and $12 \mathrm{~K}$. pneumoniae isolates and one $K$. oxytoca isolate. ESBL transfer by plasmid DNA electroporation into $E$. coli $\mathrm{DH} 10 \mathrm{~B}$ was successful for five $(10.2 \%)$ of the 20 remaining isolates; four were $E$. coli isolates and one was a $K$. pneumoniae isolate. The presence of bla $a_{\mathrm{CTX}-\mathrm{M}}$, $b l a_{\mathrm{SHV}}, b l a_{\mathrm{TEM}}$ and $b l a_{\mathrm{OXA}}$ was confirmed by PCR in the 34 transconjugants and transformants. Transfers of non-ESBL resistance genes (tetracycline, gentamicin and trimethoprim-sulfamethoxazole) were also detected by antimicrobial susceptibility testing.

\section{Plasmid replicon type determination}

PCR-based replicon typing in the 34 transconjugants and transformants demonstrated the presence of the IncFII, HI2 and FIA replicons in these isolates (Table 3). IncFII was the most prevalent replicon type and was detected in 20 (58.8\%) (10 E. coli and $10 \mathrm{~K}$. pneumoniae) of the 34 isolates. HI2 was found in $13(38.2 \%)$ isolates (eight E. cloacae, three $K$. pneumoniae, one E. coli and one $K$. oxytoca) and FIA was found in one E. coli isolate. The plasmids carrying $b l a_{\mathrm{CTX}-\mathrm{M}-15}$ were assigned to the FII $(n=12)$ and HI2 $(n=8)$ replicon types. Plasmids carrying bla $a_{\mathrm{SHV}-12}(\mathrm{n}=5)$ or carrying both bla $a_{\mathrm{CTX}-\mathrm{M}-15}$ and $b_{\text {SHV-12 }}(\mathrm{n}=2)$ were assigned to FII.

\section{E. coli phylogenetic groups and virulence factors}

Phylogenetic analysis of the $18 \mathrm{E}$. coli isolates revealed four main phylogenetic groups (A1, B1, B2 and D). Most of these isolates belonged to group A1 (77.7\%, n=14), 11 of which were isolated from pus. All 18 isolates harbored genes related to complement resistance (traT) but none harbored any of the papG alleles or the fimH, afa, hlyA, cnf1, kpsMII or sat genes. Ten isolates from groups A1, $\mathrm{B} 1$ and $\mathrm{D}$ harbored genes encoding siderophores $(f y u A$, iutA and IroN) (Table 4).

The single $E$. coli isolate in the $\mathrm{B} 2$ group was an O25b-ST131 clone and was isolated from the urine of a hospitalized patient. This $E$. coli isolate harbored bla $a_{\mathrm{CTX}-\mathrm{M}-15}$, tet $A, a a c\left(6^{\prime}\right)-I b-c r$ and sul1-sul2, and was assigned to the FII replicon type. Genes encoding siderophore (fyuA and iutA) and genes involved in the formation of adhesins (iha) or fimbriae ( $f f a$ ) were detected in this isolate, but it produced neither cytotoxin nor hemolysin.

\section{Discussion}

We extensively characterized 49 ESBL-producing Enterobacteriaceae collected over a period of 15 months in four hospitals and at the Pasteur Institute Medical Laboratory. Previous studies in Antananarivo have shown resistant bacteria clonal diffusion in hospital settings $[20,30]$, but among the 49 non-representative ESBLproducing Enterobacteriaceae studied, no clonal isolates have been found.

The bla $a_{\mathrm{CTX}-\mathrm{M}-15}$ ESBL gene is considered to be the most prevalent ESBL worldwide [17,18,23,31,32]. We also found $b l a_{\mathrm{CTX}-\mathrm{M}-15}$ to be the most prevalent ESBL in Madagascar, as it was detected in $75.5 \%$ of the isolates we studied. A study involving nine Asian countries reported that bla $a_{\mathrm{CTX}-\mathrm{M}-15}$ was highly prevalent among ESBL-producing $K$. pneumoniae isolates (60\%, 55/92) [17]. In Tunisia, Dahmen et al. reported that $91 \%$ of the ESBL-producing isolates carried $b l a_{\mathrm{CTX}-\mathrm{M}-15}$ genes [23]. Our findings are intermediate between those found in Asia and in Tunisia and confirm the predominance of $b l a_{\mathrm{CTX}-\mathrm{M}-15}$ among ESBL-producing isolates. In Antananarivo, a previous study conducted in the neonatal units of two hospitals in 2006 documented that a clonal outbreak of $K$. pneumoniae harbored $b l a_{\mathrm{CTX}-\mathrm{M}-15}$ and $b l a_{\mathrm{SHV}-2}$ genes [20]. In 2009, a community-based study of the intestinal carriage of 49 ESBL-producing Enterobacteriaceae demonstrated that the most prevalent ESBL gene was bla followed by $b l a_{\mathrm{CTX}-\mathrm{M}-3}, b l a_{\mathrm{SHV}-12}$ and $b l a_{\mathrm{SHV}-2 \mathrm{a}}$ [33]. The presences of $b l a_{\mathrm{CTX}-\mathrm{M}-15}, b l a_{\mathrm{CTX}-\mathrm{M}-3}, b l a_{\mathrm{SHV}-2}$ and $b l a_{\mathrm{SHV}-12}$ is not surprising as molecular analysis indicated that 
Table 2 Characteristics of ESBL-producing Enterobacteriaceae isolates and their associated drug resistance genes and gene cassettes ESBLs Other Associated drug resistance genes

Gene cassettes $\beta$-lactamases

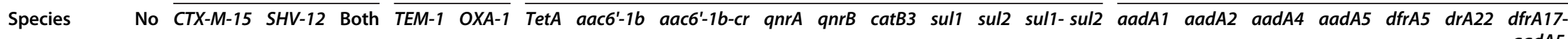

\begin{tabular}{lcccccccccccccccccccccccccccccccccc} 
aadA5 \\
\hline E. coli & 18 & 14 & 2 & 2 & 12 & 13 & 8 & 14 & 13 & 0 & 3 & 0 & 2 & 3 & 8 & 2 & 1 & 1 & 1 & 2 & 0 & 6 \\
K. pneumoniae & 14 & 6 & 3 & 5 & 7 & 13 & 9 & 13 & 13 & 0 & 5 & 4 & 2 & 5 & 7 & 0 & 2 & 0 & 0 & 1 & 1 & 3 \\
K. oxytoca & 3 & 1 & 2 & 0 & 1 & 0 & 0 & 0 & 0 & 0 & 0 & 0 & 0 & 0 & 2 & 0 & 0 & 0 & 1 & 0 & 0 & 0 \\
E. cloacae & 14 & 8 & 4 & 1 & 12 & 2 & 7 & 8 & 7 & 1 & 4 & 0 & 0 & 6 & 8 & 0 & 1 & 1 & 0 & 0 & 0 & 2 \\
Totals & 49 & 29 & 11 & 8 & 32 & 28 & 24 & 35 & 33 & 1 & 12 & 4 & 4 & 14 & 25 & 2 & 4 & 2 & 2 & 3 & 1 & 11 \\
\hline
\end{tabular}


Table $3 \beta$-lactamase genes transferred to transconjugants and electroporants and their replicon type

\begin{tabular}{|c|c|c|c|c|c|c|c|c|c|}
\hline \multirow[t]{2}{*}{$\beta$-lactamase genes } & \multirow[t]{2}{*}{ Replicon type } & \multicolumn{4}{|c|}{ Transconjugants } & \multirow[b]{2}{*}{ Totals } & \multicolumn{2}{|c|}{ Electroporants } & \multirow[b]{2}{*}{ Total } \\
\hline & & E. coli & K. pneumoniae & K. oxytoca & E. cloacae & & E. coli & K. pneumoniae & \\
\hline \multirow[t]{3}{*}{ CTX-M-15 } & FII & 2 & 1 & 0 & 0 & 3 & 2 & 0 & 2 \\
\hline & $\mathrm{HI} 2$ & 0 & 1 & 0 & 1 & 2 & 0 & 0 & \\
\hline & $\mathrm{FIA} / \mathrm{FIB}$ & 1 & 0 & 0 & 0 & 1 & 0 & 0 & \\
\hline SHV-12 & FII & 0 & 3 & 0 & 0 & 3 & 1 & 0 & 1 \\
\hline OXA-1 & FII & 0 & 1 & 0 & 0 & 1 & 0 & 0 & \\
\hline \multirow[t]{2}{*}{ CTX-M-15+TEM-1 } & FII & 0 & 0 & 0 & 0 & & 1 & 0 & 1 \\
\hline & $\mathrm{HI} 2$ & 0 & 0 & 1 & 6 & 7 & 0 & 0 & \\
\hline \multirow[t]{2}{*}{ CTX-M-15+OXA-1 } & Fll & 3 & 3 & 0 & 0 & 6 & 0 & 0 & \\
\hline & $\mathrm{HI} 2$ & 1 & 1 & 0 & 0 & 2 & 0 & 0 & \\
\hline SHV-12+TEM-1 & FII & 1 & 0 & 0 & 0 & 1 & 0 & 0 & \\
\hline TEM-1+OXA-1 & $\mathrm{HI} 2$ & 0 & 0 & 0 & 1 & 1 & 0 & 0 & \\
\hline CTX-M-15+SHV-12+TEM-1 & Fll & 0 & 0 & 0 & 0 & & 0 & 1 & 1 \\
\hline CTX-M-15+TEM-1+OXA-1 & $\mathrm{HI} 2$ & 0 & 1 & 0 & 0 & 1 & 0 & 0 & \\
\hline CTX-M-15+SHV-12+OXA-1 & FII & 0 & 1 & 0 & 0 & 1 & 0 & 0 & \\
\hline Totals & & 8 & 12 & 1 & 8 & 29 & 4 & 1 & 5 \\
\hline
\end{tabular}

bla $a_{\mathrm{CTX}-\mathrm{M}-15}$ derived from $b l a_{\mathrm{CTX}-\mathrm{M}-3}$ [6] and $b l a_{\mathrm{SHV}-12}$ from bla $_{\mathrm{SHV}-2}$ [34].

CTX-M genes may disseminate through clonal expansion or horizontal gene transfer $[35,36]$. In our study, ISEcp1 was found upstream from $b l a_{\mathrm{CTX}-\mathrm{M}-15}$ at variable distances, as was previously described [18]. ISEcp1 was found to be in the vicinity of many bla $a_{\mathrm{CTX}-\mathrm{M}}$ genes (including bla $\left.a_{\mathrm{CTX}-\mathrm{M}-15}\right)$ and was reported to contain sequences resembling a typical promoter region [11]. Then, plasmids carrying $b l a_{\mathrm{CTX}-\mathrm{M}-15}$ were assigned to the IncFII, IncFIA or IncHI2 incompatibility group replicons. Association of the $b l a_{\mathrm{CTX}-\mathrm{M}-15}$ gene with IncF plasmids carrying the FII replicon in association with the FIA or FIB replicon has been reported previously for isolates in Canada, France, Spain, Tunisia, and the United Kingdom [35,36]. The first evidence of the association of the FII plasmid with the

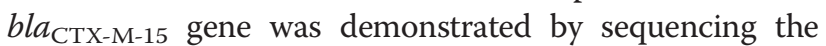
entire pC15-1a plasmid from epidemic E. coli isolated in Canada [2]. The IncHI2 plasmid, frequently associated with bla $a_{\mathrm{CTX}-\mathrm{M}-2}$ or bla $a_{\mathrm{CTX}-\mathrm{M}-9}$, was first identified in
Serratia marcescens [10], but rarely reported in association with bla $a_{\mathrm{CTX}-\mathrm{M}-15}$.

Like $b l a_{\mathrm{CTX}-\mathrm{M}-15}, b l a_{\mathrm{SHV}-12}$ is also widely distributed. In our study, $38 \%$ of the isolates harbored $b l a_{\mathrm{SHV}-12}$. First described in Switzerland [37] and subsequently found in various continents, including Africa [38], bla $a_{\mathrm{SHV}-12}$ is most often found in Asia [34]. Plasmids carrying $b l a_{\mathrm{SHV}-12}$ were assigned to the IncFII replicon, as previously reported in France [39]. Evolutionary analysis of GenBank sequences indicated that $b l a_{\mathrm{SHV}-12}$ evolved from the branch of $b l a_{\mathrm{SHV}-2 \mathrm{a}}$ [34]. Although it is possible that this transformation occurred in Antananarivo, as bla $a_{\mathrm{SHV}-2 \mathrm{a}}$ was reported in neonatal units in 2009 [20]. It can also be assumed that the local emergence of $b l a_{\mathrm{SHV}-12}$ could be explained by introduction of international clones.

Our antimicrobial susceptibility analysis of the ESBLproducing isolates found highly prevalent resistances to gentamicin (87.7\%); tobramycin (93.8\%); ciprofloxacin $(69.3 \%)$ and to trimethoprim-sulfamethoxazole (100\%) and confirm the presence of multidrug-resistant isolates in

Table 4 Phylogenetic and virulence factors in the $E$. coli isolates

\begin{tabular}{|c|c|c|c|c|c|c|c|c|c|c|c|}
\hline \multirow{2}{*}{$\begin{array}{l}\text { Phylogenetic } \\
\text { group }\end{array}$} & \multirow[t]{2}{*}{ No } & \multicolumn{4}{|c|}{ Specimen } & \multicolumn{6}{|c|}{ Virulence factor } \\
\hline & & Pus* & Urine & Sputum & CSF & fyuA & iutA & sfa & IroN & Iha & trat \\
\hline $\mathrm{A} 1$ & 14 & 11 & 1 & 1 & 1 & 3 & 6 & 0 & 2 & 0 & 14 \\
\hline B1 & 2 & 1 & 1 & 0 & 0 & 1 & 1 & 0 & 0 & 0 & 2 \\
\hline B2 & 1 & 0 & 1 & 0 & 0 & 1 & 1 & 1 & 0 & 1 & 1 \\
\hline D1 & 1 & 0 & 1 & 0 & 0 & 1 & 1 & 0 & 0 & 0 & 1 \\
\hline Totals & 18 & 12 & 4 & 1 & 1 & 6 & 9 & 1 & 2 & 1 & 18 \\
\hline
\end{tabular}

*Deep pus, surgical wounds. 
Antananarivo [19,22]. The finding of multidrug resistance among ESBL-producing isolates is of great clinical relevance due to the severely limited therapeutic options and the high risk of treatment failure in patients infected with these strains.

Genes encoding ESBLs are often associated with determinants of resistance to other antimicrobial agents, including aminoglycosides (aac(6)-Ib), fluoroquinolones $(q n r)$, tetracycline (tet $A)$, and trimethoprim-sulfamethoxazole $(s u l)$ and are frequently located on plasmids belonging to the IncF group [10]. In this study, we found the first example in Madagascar of the plasmid-mediated quinolone resistance (PMQR) genes: $q n r B(24.5 \%)$ and $q n r A(2 \%)$, and a variant gene $a a c\left(6^{\prime}\right)-I b-c r(67.3 \%)$ that encodes an aminoglycoside-modifying enzyme. Qnr gene prevalence was higher in the $K$. pneumoniae $(41.7 \%)$ isolates than in the E. coli (25\%) isolates, which has been noted by other authors [24,40]. The aac $\left(6^{\prime}\right)-I b-c r$ gene accounted for $94.3 \%$ (33/35) of the $a a c\left(6^{\prime}\right)$-Ib genes detected. This high proportion of $a a c\left(6^{\prime}\right)-I b-c r / a a c\left(6^{\prime}\right)-I b$ was also observed in a previous study [40]. The PMQR genes $q n r$ and $a a c\left(6^{\prime}\right)-I b-c r$ are now recognized to be geographically widespread [24,25]. These genes have been previously reported to be associated with ESBLs. The horizontal transfer of plasmids harboring genes encoding for ESBLs and PMQR genes could have promoted this co-resistance.

The cassette region could not be amplified by PCR in 23 class 1 integron-containing isolates, which may have been due to the lack of the $3^{\prime} \mathrm{CS}$. The analysis of 25 cassette regions revealed a predominance of $\operatorname{adA} A$ and $d f r A$ genes, which confer resistance to aminoglycosides and trimethoprim, respectively. This result correlates with previous studies of African Enterobacteriaceae isolates $[27,41]$. The combination of $d$ frA17-aadA5 (22\%) was the one most frequently detected in our study. Similar findings were reported for isolates from Taiwan and Tunisia, as $d$ frA17-aadA5 was found in 81 of 224 (36\%) and in 3 of 4 (75\%) E. coli class 1 integrons, respectively $[42,43]$.

Analysis of the phylogenetic groups and virulence factors of $E$. coli isolates revealed that most of these isolates belong to group A1. The phylogenetic group A1 consists of commensal enteric $E$. coli and may therefore be the natural reservoir of pathogenic isolates. Pathogenic E. coli isolates may have derived from commensal isolates by acquiring chromosomal or extra chromosomal virulence operons [44]. Although virulence determinants are considered to be mobile, strain phylogeny and virulence may be linked [45]. The B2 phylogenetic group, which diverges from the commensal isolates, evolved toward extra intestinal virulence by acquiring numerous pathogenic determinants [12].

We also encountered an $E$. coli isolate belonging to group B2, harboring bla ${ }_{\mathrm{CTX}-\mathrm{M}-15}$ and other resistance genes, and corresponding to the worldwide pandemic clone O25b-ST131. It has been reported that most O25-ST131 isolates are multidrug-resistant, produce CTX-M-15 ESBL enzymes [14] and harbor virulence genes required for pathogenic invasion of hosts. In one study, the genes for adhesins (iha, fimH), siderophores $(f y u A, i u t A)$ and the toxin (sat) were found in 95\% - 100\% of the O25b-ST131 E. coli isolates [14], but typical fimbriae and pilus genes, such as those encoded by the papA allele, were not. In Africa, few data exist on the presence of ST131. In a South African study, 43\% of 23 isolates were ST131 [46]; as were 50\% of the CTX-M-15producing E. coli isolates collected in the Central African Republic [13]. The presence of this clone in Antananarivo hospitals is of concern and further studies should be conducted to assess its prevalence.

\section{Conclusion}

Our results highlight the dissemination of multidrug resistant Enterobacteriaceae isolates in Antananarivo, in different hospital settings and probably in the community. These findings underline the need for a rational use of antibiotic and for appropriate methods of screening ESBL in routine laboratories in Antananarivo.

\section{Competing interest}

The authors declare that they have no competing interests.

\section{Authors' contributions}

Conception and design of the study and acquisition of data: HCR, FR, VR, AT, GA. Molecular and genetic studies, molecular analysis: HCR, GA. Analysis of results: HCR, FR, VR, AT, GA. Draft of the manuscript: $H C R, F R, B G, A T, G A$. Revisiting of the manuscript for important intellectual content: VR, BG, AT and GA. All authors have read and approved the final manuscript.

\section{Acknowledgements}

We thank Delphine Geneste and Nathalie Genel, for technical assistance, for participation in molecular studies. This study was performed with grants from Institut Pasteur de Madagascar and from Pierre and Marie Curie University.

\section{Author details}

'Institut Pasteur de Madagascar, Antananarivo 101, BP 1274, Madagascar. ${ }^{2}$ Institut Pasteur de Dakar, 36 Avenue Pasteur, Dakar BP 220, Senegal. ${ }^{3}$ Institut Pasteur de Guadeloupe, Morne Jolivière, 97183 Les Abymes, Guadeloupe BP 484, France. ${ }^{4}$ Faculté de Médecine, Laboratoire de Bactériologie, Université Pierre et Marie Curie, Paris 6, 27 rue Chaligny, Paris 75012, France. ${ }^{5}$ Assistance Publique Hôpitaux de Paris, Hôpital Tenon, Laboratoire de Bactériologie, 4 rue de la Chine, Paris 75970, France.

Received: 19 November 2012 Accepted: 22 March 2013 Published: 17 April 2013

\section{References}

1. Bradford PA: Extended-spectrum beta-lactamases in the 21st century: characterization, epidemiology, and detection of this important resistance threat. Clin Microbio/ Rev 2001, 14:933-951. table of contents.

2. Boyd DA, Tyler S, Christianson S, McGeer A, Muller MP, et al: Complete nucleotide sequence of a 92-kilobase plasmid harboring the CTX-M-15 extended-spectrum beta-lactamase involved in an outbreak in long-term-care facilities in Toronto, Canada. Antimicrob Agents Chemother 2004, 48:3758-3764 
3. Kliebe C, Nies BA, Meyer JF, Tolxdorff-Neutzling RM, Wiedemann B: Evolution of plasmid-coded resistance to broad-spectrum cephalosporins. Antimicrob Agents Chemother 1985, 28:302-307.

4. Sougakoff W, Goussard S, Gerbaud G, Courvalin P: Plasmid-mediated resistance to third-generation cephalosporins caused by point mutations in TEM-type penicillinase genes. Rev Infect Dis 1988, 10:879-884.

5. Pitout JD, Laupland KB: Extended-spectrum beta-lactamase-producing Enterobacteriaceae: an emerging public-health concern. Lancet Infect Dis 2008, 8:159-166.

6. Bonnet R: Growing group of extended-spectrum beta-lactamases: the CTX-M enzymes. Antimicrob Agents Chemother 2004, 48:1-14.

7. Humeniuk C, Arlet G, Gautier V, Grimont P, Labia R, et al: Beta-lactamases of Kluyvera ascorbata, probable progenitors of some plasmid-encoded CTX-M types. Antimicrob Agents Chemother 2002, 46:3045-3049.

8. Coque TM, Novais A, Carattoli A, Poirel L, Pitout J, et al: Dissemination of clonally related Escherichia coli strains expressing extended-spectrum beta-lactamase CTX-M-15. Emerg Infect Dis 2008, 14:195-200

9. Poirel L, Kampfer P, Nordmann P: Chromosome-encoded Ambler class A beta-lactamase of Kluyvera georgiana, a probable progenitor of a subgroup of CTX-M extended-spectrum beta-lactamases. Antimicrob Agents Chemother 2002, 46:4038-4040.

10. Carattoli A: Resistance plasmid families in Enterobacteriaceae. Antimicrob Agents Chemother 2009, 53:2227-2238.

11. Poirel L, Naas T, Nordmann P: Genetic support of extended-spectrum beta-lactamases. Clin Microbiol Infect 2008, 14(Suppl 1):75-81.

12. Picard B, Garcia JS, Gouriou S, Duriez P, Brahimi N, et al: The link between phylogeny and virulence in Escherichia coli extraintestinal infection. Infect Immun 1999, 67:546-553.

13. Clermont O, Bonacorsi S, Bingen E: Rapid and simple determination of the Escherichia coli phylogenetic group. Appl Environ Microbiol 2000, 66:4555-4558.

14. Nicolas-Chanoine MH, Blanco J, Leflon-Guibout V, Demarty R, Alonso MP, et al: Intercontinental emergence of Escherichia coli clone O25:H4-ST131 producing CTX-M-15. J Antimicrob Chemother 2008, 61:273-281.

15. Rogers BA, Sidjabat HE, Paterson DL: Escherichia coli O25b-ST131: a pandemic, multiresistant, community-associated strain. J Antimicrob Chemother 2011, 66:1-14.

16. Mamlouk K, Boutiba-Ben Boubaker I, Gautier V, Vimont S, Picard B, et al: Emergence and outbreaks of CTX-M beta-lactamase-producing Escherichia coli and Klebsiella pneumoniae strains in a Tunisian hospital. J Clin Microbiol 2006, 44:4049-4056.

17. Lee MY, Ko KS, Kang $\mathrm{Cl}$, Chung DR, Peck KR, et al: High prevalence of CTX-M-15-producing Klebsiella pneumoniae isolates in Asian countries: diverse clones and clonal dissemination. Int J Antimicrob Agents 2011, 38:160-163.

18. Eckert C, Gautier V, Saladin-Allard M, Hidri N, Verdet C, et al: Dissemination of CTX-M-type beta-lactamases among clinical isolates of Enterobacteriaceae in Paris, France. Antimicrob Agents Chemother 2004, 48:1249-1255.

19. Randrianirina F, Soares JL, Carod JF, Ratsima E, Thonnier V, et al: Antimicrobial resistance among uropathogens that cause communityacquired urinary tract infections in Antananarivo, Madagascar. J Antimicrob Chemother 2007, 59:309-312.

20. Randrianirina F, Vedy S, Rakotovao D, Ramarokoto CE, Ratsitohaina $\mathrm{H}$, et al: Role of contaminated aspiration tubes in nosocomial outbreak of Klebsiella pneumoniae producing SHV-2 and CTX-M-15 extended-spectrum betalactamases. J Hosp Infect 2009, 72:23-29.

21. Randrianirina F, Vaillant L, Ramarokoto CE, Rakotoarijaona A, Andriamanarivo $\mathrm{ML}$, et al: Antimicrobial resistance in pathogens causing nosocomial infections in surgery and intensive care units of two hospitals in Antananarivo, Madagascar. J Infect Dev Ctries 2010, 4:74-82.

22. Andriatahina T, Randrianirina F, Hariniana ER, Talarmin A, Raobijaona $H$, et al: High prevalence of fecal carriage of extended-spectrum beta-lactamase -producing Escherichia coli and Klebsiella pneumoniae in a pediatric unit in Madagascar. BMC Infect Dis 2010, 10:204.

23. Dahmen S, Bettaieb D, Mansour W, Boujaafar N, Bouallegue O, et al: Characterization and molecular epidemiology of extended-spectrum beta-lactamases in clinical isolates of Enterobacteriaceae in a Tunisian University Hospital. Microb Drug Resist 2010, 16:163-170.

24. Robicsek A, Jacoby GA, Hooper DC: The worldwide emergence of plasmid-mediated quinolone resistance. Lancet Infect Dis 2006, 6:629-640.
25. Robicsek A, Strahilevitz J, Jacoby GA, Macielag M, Abbanat D, et al: Fluoroquinolone-modifying enzyme: a new adaptation of a common aminoglycoside acetyltransferase. Nat Med 2006, 12:83-88.

26. Park CH, Robicsek A, Jacoby GA, Sahm D, Hooper DC: Prevalence in the United States of aac $\left(6^{\prime}\right)-\mathrm{lb}$-cr encoding a ciprofloxacin-modifying enzyme. Antimicrob Agents Chemother 2006, 50:3953-3955.

27. Frank T, Gautier V, Talarmin A, Bercion R, Arlet G: Characterization of sulphonamide resistance genes and class 1 integron gene cassettes in Enterobacteriaceae, Central African Republic (CAR). J Antimicrob Chemother 2007, 59:742-745.

28. Carattoli A, Bertini A, Villa L, Falbo V, Hopkins KL, et al: Identification of plasmids by PCR-based replicon typing. J Microbiol Methods 2005, 63:219-228.

29. Clermont O, Dhanji H, Upton M, Gibreel T, Fox A, et al: Rapid detection of the O25b-ST131 clone of Escherichia coli encompassing the CTX-M-15producing strains. J Antimicrob Chemother 2009, 64:274-277.

30. Andriamanantena TS, Ratsima E, Rakotonirina HC, Randrianirina F, Ramparany L, et al: Dissemination of multidrug resistant Acinetobacter baumannii in various hospitals of Antananarivo Madagascar. Ann Clin Microbiol Antimicrob 2010, 9:17.

31. Pallecchi L, Bartoloni A, Fiorelli C, Mantella A, Di Maggio T, et al: Rapid dissemination and diversity of CTX-M extended-spectrum betalactamase genes in commensal Escherichia coli isolates from healthy children from low-resource settings in Latin America. Antimicrob Agents Chemother 2007, 51:2720-2725.

32. Canton R, Coque TM: The CTX-M beta-lactamase pandemic. Curr Opin Microbiol 2006, 9:466-475.

33. Herindrainy P, Randrianirina F, Ratovoson R, Ratsima Hariniana E, Buisson $Y$, et al: Rectal carriage of extended-spectrum Beta-lactamase-producing gram-negative bacilli in community settings in madagascar. PLoS One 2011, 6:e22738.

34. Kim J, Kwon Y, Pai H, Kim JW, Cho DT: Survey of Klebsiella pneumoniae strains producing extended-spectrum beta-lactamases: prevalence of SHV-12 and SHV-2a in Korea. J Clin Microbiol 1998, 36:1446-1449.

35. Lavollay M, Mamlouk K, Frank T, Akpabie A, Burghoffer B, et al: Clonal dissemination of a CTX-M-15 beta-lactamase-producing Escherichia coli strain in the Paris area, Tunis, and Bangui. Antimicrob Agents Chemother 2006, 50:2433-2438.

36. Novais A, Canton R, Moreira R, Peixe L, Baquero F, et al: Emergence and dissemination of Enterobacteriaceae isolates producing CTX-M-1-like enzymes in Spain are associated with IncFII (CTX-M-15) and broad-host-range (CTX-M-1, -3, and -32) plasmids. Antimicrob Agents Chemother 2007, 51:796-799.

37. Nuesch-Inderbinen MT, Kayser FH, Hachler H: Survey and molecular genetics of SHV beta-lactamases in Enterobacteriaceae in Switzerland: two novel enzymes, SHV-11 and SHV-12. Antimicrob Agents Chemother 1997, 41:943-949.

38. Kasap M, Fashae K, Torol S, Kolayli F, Budak F, et al: Characterization of ESBL (SHV-12) producing clinical isolate of Enterobacter aerogenes from a tertiary care hospital in Nigeria. Ann Clin Microbiol Antimicrob 2010, 9:1.

39. Marcade G, Deschamps C, Boyd A, Gautier V, Picard B, et al: Replicon typing of plasmids in Escherichia coli producing extended-spectrum betalactamases. J Antimicrob Chemother 2009, 63:67-71.

40. Jiang Y, Zhou Z, Qian Y, Wei Z, Yu Y, et al: Plasmid-mediated quinolone resistance determinants qnr and aac(6')-lb-cr in extended-spectrum beta-lactamase-producing Escherichia coli and Klebsiella pneumoniae in China. J Antimicrob Chemother 2008, 61:1003-1006.

41. Dahmen S, Mansour W, Boujaafar N, Arlet G, Bouallegue O: Distribution of cotrimoxazole resistance genes associated with class 1 integrons in clinical isolates of Enterobacteriaceae in a university hospital in Tunisia. Microb Drug Resist 2010, 16:43-47.

42. Chang LL, Chang TM, Chang CY: Variable gene cassette patterns of class 1 integron-associated drug-resistant Escherichia coli in Taiwan. Kaohsiung J Med Sci 2007, 23:273-280

43. Jouini A, Ben Slama K, Vinue L, Ruiz E, Saenz Y, et al: Detection of unrelated Escherichia coli strains harboring genes of CTX-M-15, OXA-1, and AAC(6')$\mathrm{lb}$-cr enzymes in a Tunisian hospital and characterization of their integrons and virulence factors. J Chemother 2010, 22:318-323.

44. Johnson JR, Stell AL, Delavari P, Murray AC, Kuskowski M, et al: Phylogenetic and pathotypic similarities between Escherichia coli isolates from urinary tract infections in dogs and extraintestinal infections in humans. $J$ Infect Dis 2001, 183:897-906. 
45. Johnson JR, Goullet P, Picard B, Moseley SL, Roberts PL, et al: Association of carboxylesterase $B$ electrophoretic pattern with presence and expression of urovirulence factor determinants and antimicrobial resistance among strains of Escherichia coli that cause urosepsis. Infect Immun 1991, 59:2311-2315.

46. Peirano G, Pitout JD: Molecular epidemiology of Escherichia coli producing CTX-M beta-lactamases: the worldwide emergence of clone ST131 O25:H4. Int J Antimicrob Agents 2011, 35:316-321.

doi:10.1186/1471-2180-13-85

Cite this article as: Rakotonirina et al:: Molecular characterization of multidrug-resistant extended-spectrum $\beta$-lactamase-producing Enterobacteriaceae isolated in Antananarivo, Madagascar. BMC Microbiology 2013 13:85.

\section{Submit your next manuscript to BioMed Central and take full advantage of:}

- Convenient online submission

- Thorough peer review

- No space constraints or color figure charges

- Immediate publication on acceptance

- Inclusion in PubMed, CAS, Scopus and Google Scholar

- Research which is freely available for redistribution 